\title{
高校生と高齢者の高血圧の知識の差に関する実態調査
}

\author{
真川明将, ${ }^{a, b, c}$ 小笠原美沙, ${ }^{a, d}$ 草原ゆり, ${ }^{a, e}$ 安本美貴, ${ }^{a, f}$ 岩城壮一郎, ${ }^{a}$ 藤井 $\quad$ 聡 $*, a, g, h$
}

\section{Investigation into Differences in Level of Knowledge about Hypertension between High School Students and Elderly People}

\begin{abstract}
Akimasa Sanagawa, ${ }^{a, b, c}$ Misa Ogasawara, ${ }^{a, d}$ Yuri Kusahara, ${ }^{a, e}$
Miki Yasumoto, ${ }^{a, f}$ Soichiro Iwaki, ${ }^{a}$ and Satoshi Fujii ${ }^{*, a, g, h}$

${ }^{a}$ Department of Molecular and Cellular Pathobiology and Therapeutics, Graduate School of Pharmaceutical Sciences, Nagoya City University; 3-1 Tanabe do-ri, Mizuho-ku, Nagoya 467-8603, Japan: ${ }^{b}$ Department of Pharmacy, Nagoya City University Hospital; 1-Kawasumi, Mizuho-cho, Mizuho-ku, Nagoya 467-8601, Japan: 'Department of Hospital Pharmacy, Graduate School of Pharmaceutical Sciences, Nagoya City University; 3-1 Tanabe do-ri, Mizuho-ku, Nagoya 467-8603, Japan: ${ }^{d}$ Department of Pharmacy, TOYOTA Memorial Hospital; 1-1 Heiwa-cho, Toyota,

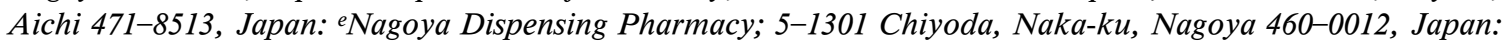

${ }^{f}$ Sundrug Co., Ltd.; 1-38-1 Wakamatsu-cho, Fuchu, Tokyo 183-0012, Japan: ${ }^{g}$ Department of Laboratory Medicine, Asahikawa Medical University; Midorigaoka-Higashi 2-1-1-1, Asahikawa, Hokkaido 078-8510, Japan: and ${ }^{h}$ Medical Laboratory and Blood Center, Asahikawa Medical University Hospital; Midorigaoka-Higashi 2-1-1-1, Asahikawa, Hokkaido 078-8510, Japan.
\end{abstract}

(Received January 11, 2017; Accepted February 9, 2017)

As a major chronic non-communicable disease, hypertension is the most important risk factor for cardiovascular disease, chronic kidney disease, stroke and, if not treated appropriately, premature death. A population-based approach aimed at decreasing high blood pressure among the general population is an important component of any comprehensive plan to prevent hypertension. However, few studies have investigated generational differences in knowledge about, and consciousness of, hypertension. Thus, we conducted a questionnaire survey about hypertension, with the aim of clarifying differences of understanding about hypertension between high school students and elderly people. The results of this investigation suggested that there is indeed a generational difference: knowledge about hypertension, and awareness of its relationship with salt intake, was higher in elderly people than in high school students. Furthermore, our study showed that among high school students, salt intake consciousness correlated with a family history of hypertension. By contrast, in elderly people, salt intake consciousness is related to age and to an awareness of recommended daily salt intake. This study strongly showed that knowledge and consciousness of hypertension varied among generations, with the elderly being more aware and conscientious about salt intake. Acknowledgement of this generational diversity is critical to developing an effective overall preventive strategy for hypertension.

Key words - hypertension; population-based approach; high school student; elderly people; health consciousness

\section{緒言}

高血圧は心血管疾患, 腎疾患, 脳血管疾患の最も 重要な危険因子である. ${ }^{1-3)}$

また，心血管病過剰死亡・罹患の半数以上は I 度 高血圧以下の比較的軽度の血圧高值の範囲から発生

$a$ 名古屋市立大学大学院薬学研究科病態解析学, $b$ 名古 屋市立大学病院薬剤部, $c$ 名古屋市立大学大学院薬学研 究科病院薬剤学, $d$ 卜ヨ夕記念病院薬剂科, eなごや調 剂薬局, $f$ 株式会社サンドラッグ, $g$ 旭川医科大学臨床 検查医学講座, h旭川医科大学病院臨床検査・輸血部

*e-mail: sfujii@asahikawa-med.ac.jp
していることが指摘されている．国民全体の血圧分 布を低い方向へシフトさせるための国民戦略が健康 寿命を延長するために重要と考えられる. ${ }^{4}$

健康日本 21 では個人を取り巻く社会に着目し, 「マスメディア，企業，非営利団体，職場・学校・ 家庭，保険者，専門家などの，健康関連グループが あり，制度，情報，商品，サービスなどの健康資源 の提供を通じて，個人の健康の実現に大きく貢献す

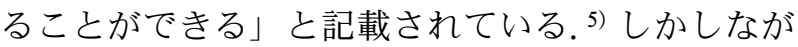
ら，健康の課題は世代によって異なっており，高齢 者から若年層まで幅広い年代層における健康意識や 知識の程度を理解することは非常に重要である。し 
1. 高血圧とは高い方の血圧がいくつ以上をさすと思いますか.
(1) $120 \mathrm{mmHg}$
(2) $140 \mathrm{mmHg}$
(3) $160 \mathrm{mmHg}$
(4) $180 \mathrm{mmHg}$

2. 高血圧の原因となる状態をいくつでもあげてください.
(1) 塩分のとりすぎ
(2) 肥満
(3) 糖尿病
(4) 運動不足

3. 高血圧があると括こりやすい病気をいくつでもあげてください.
(1) 心臓病
(2) 脳卒中
(3) 腎臓病
(4) 胃潰瘍

4. 高血圧があるとおこりやす寸症状をいくつでもあげてください.
(1) 頭痛
(2) 肩 $こ り$
(3) 動悸
(4)めまい

5. 血圧の測定に最もよい場所はどこですか.ひとつあげてください.
(1) 手首
(2) 指先
(3) 足首
(4) 上腕

6. 普段の食生活で塩分のとりすぎに注意していますか.
（1）注意している （2）注意していない

7. 1 日の塩分摄取量として勧められるのは何 $\mathrm{g}$ 末満でしょらか。
(1) $12 \mathrm{~g}$
(2) $10 \mathrm{~g}$
(3) $8 g$
(4) $6 \mathrm{~g}$

8. ある食品の袋に Na（ナトリウム）1gと書いてありました. この食品には食篮 $(\mathrm{NaCl})$ は何 $\mathrm{g}$ 入っているでしょうか.
(1) $1.0 \mathrm{~g}$
(2) $1.5 \mathrm{~g}$
(3) $2.0 \mathrm{~g}$
(4) $2.5 \mathrm{~g}$

9. 以下の運動の中で有酸素運動をいくつでもあげてください.
(1) 相撲
(2) 重量挙げ
（3）水泳
(4) 自転車

10.家族に高血圧の人はいますか.
(1) いる
(2) いない
(3) わからない

11. 高血圧のくすりは一度はじめると一生やめられないと思いますか.
（1）休むことはできる
(2)一生やめられない
(3) わからない

Fig. 1. Contents of the Questions about Hypertension

かし，世代間の高血圧に対する知識や認識の差は明 らかになっていない.

本研究の目的は, 年代の異なる一般住民における 血圧に対する理解の程度を明らかにし，効果的な高 血圧予防戦略に役立てることである。われわれは, 高校生と高齢者を対象に高血圧に対する知識を問う アンケート調査を施行した.

\section{方法}

1. 対象者 2012 年 7 月に大学紹介フェアを 受講した東海地区の高校生 146 名と 2012 年 10 月に 名古屋市年金制度説明会を受講した東海地区の高齢 者 447 名を対象とした.

2. 対象とする資料 各々の講演会で実施した 無記名アンケート調査の回答を対象とした（Fig.
1)。配布及び回収は，講演者及び運営スタッフが 行った.

質問項目は全部で 11 項目とした．質問項目の 6 と 10 は回答者の属性に関する質問であり，それ以 外の質問は高血圧の知識に関する問題である. アン ケートの質問 6 と 10 を除く 9 つの質問項目に関し て上から順番にQ1 から Q9 までの番号をつけた. 高血圧の基準や減塩の基準等，知識に関する問題は 日本高血圧学会ガイドライン 2009 に準じて作成し た. ${ }^{\text {) }}$

Figure 1 の各質問は以下の解答を正解とした.

Q1 : (2) $140 \mathrm{mmHg}$.

Q2：（1）塩分のとりすぎ，（2）肥満，（3）糖尿 病，(4) 運動不足のすべて.

Q3：(1) 心臟病, (2) 脳卒中, (3) 腎臓病の 3 つ. 
Q4：解なし.

$\mathrm{Q} 5$ ：(4) 上腕.

Q6 : (4) $6 \mathrm{~g}$.

$\mathrm{Q} 7:$ (4) $2.5 \mathrm{~g}$.

Q8：(3) 水泳，（4）自転車の 2つ.

Q9：(2) 一生やめられない.

3. 解析方法 統計学的解析は, IBM 社の IBM SPSS Statistics version 23.0 を用いて行った。 $2 \times 2$ のクロス集計はカイ二乗検定若しくはフィッ シャーの正確検定で検定した。有意水準は 0.05 と した.

4. 倫理的配慮 匿名化に関しては，無記名式 のアンケートとすることで行った.

本研究は，患者の特定ができないように連結不可 能匿名化されている情報を収集したため研究に関す る倫理指針の対象外となる.

結果

高校生と高齢者の属性を Table 1 に示す. 高齢者 については，性別と年齢層の情報も得られた。家族 に高血圧既往がない，若しくは家庭内の高血圧既往 について知らない割合は高校生が $70.5 \%$ であり, 高齢者は $47.9 \%$ あっった。また，塩分摂取の意識 をしている高校生は $49.3 \%$ ，高齢者は $75.6 \%$ であ り，高齢者の高血圧への関心や食塩に対する意識は 高校生よりも高い結果となつた.

Table 2 にアンケートの Q1 から Q9 の質問に対 する高校生と高齢者の正答率を示す。高血圧とは高 い方の血圧がいくつ以上をさすと思いますか（Q1） の正答率は高校生が $46.6 \%$ ，高齢者が $62.6 \%$ と高 齢者のほうが高かつた．また，高血圧の原因となる 状態をいくつでもあげてください（Q2）と高血圧 があるとおこりやすい病気をいくつでもあげてくだ さい（Q3）の正答率はそれぞれ高校生 $22.6 \%$ ，高 齢者 $22.1 \%$ と高校生 $16.4 \%$ ，高齢者 $17.0 \%$ と差が なかった，高血圧があるとおこりやすい症状をいく つでもあげてください（Q4）の正答率は高校生 0 $\%$ ，高齢者 $0.2 \%$ と低かった。血圧の測定に最もよ い場所はどこですか（Q5）の正答率は高校生 67.8 \%, 高齢者 $86.8 \%$ であり，高齢者のほうが高かつ た. 1 日の塩分㩒取量として勧められるのは何 $\mathrm{g}$ 未 満でしょうか（Q6）では高校生は $51.4 \%$ ，高齢者 は $57.0 \%$ と差がなかった。ある食品の袋に Na（ナ
Table 1. Characteristics of the High School Students and Elderly People

\begin{tabular}{lccc}
\hline \hline Characteristic & $\begin{array}{c}\text { High school } \\
\text { students } \\
(n=146)\end{array}$ & $\begin{array}{c}\text { Elderly } \\
\text { people } \\
(n=447)\end{array}$ & $p$-value \\
\hline Gender & & & \\
$\quad$ Males & - & $363(81.2)$ & - \\
Females & - & $84(18.8)$ & - \\
Age & - & 143 & - \\
$60-64$ & - & 74 & - \\
$65-69$ & - & 80 & - \\
$70-74$ & - & 150 & - \\
$75-$ & & &
\end{tabular}

Are you careful not to take too much salt?

$\begin{array}{llll}\text { Yes } & 72(49.3) & 338(75.6) & <0.001^{*} \\ \text { No } & 74(50.7) & 109(24.4) & \end{array}$

Is there any history of high blood pressure in your family? Yes $\quad 43(29.5) \quad 233(52.1)<0.001^{*}$ No or I don't know $103(70.5) \quad 214(47.9)$

Fischer's exact used for expected cell counts less than $5 .{ }^{*}$ Statistical significance.

トリウム） $1 \mathrm{~g}$ と書いてありました。この食品には 食塩 $(\mathrm{NaCl})$ は何 $\mathrm{g}$ 入っているでしょうか $(\mathrm{Q} 7)$ の正答率は高校生 $32.9 \%$, 高齢者 $11.2 \%$ であり, 高校生のほうが高かった．以下の運動の中で有酸素 運動をいくつでもあげてください（Q8）について は高校生 $52.1 \%$ ，高齢者 $56.8 \%$ と差がなかつた。 高血圧のくすりは一度はじめると一生やめられない と思いますか（Q9）の正答率は高校生が $27.4 \%$, 高齢者が 45.6\%で，高齢者の正答率が高かった.

Table 3 に高校生と高齢者の回答内訳に差が生じ た項目を示す。

Q2 の回答内訳をみると，塩分のとりすぎについ ては高校生，高齢者はそれぞれ $89.7 \% ， 90.8 \% の 人$ が回答に挙げており，差がなかった。しかし，肥満 と糖尿病についてはそれぞれ $82.2 \% ， 68.0 \%$ と $45.2 \% ， 35.3 \%$ とどちらも高校生の回答率が高かっ た．運動不足は $48.6 \% ， 59.1 \%$ となっており，高齡 者の回答率が高かった.

Q3 の回答内訳では，心臟病は高校生，高齢者は それぞれ $82.2 \%, 72.0 \%$ のが回答しており，高校 生の回答率が高かった。しかし，脳卒中については $86.3 \%, 93.3 \%$ で，高齢者の回答率が高い。腎臓病 は 37.0\%，24.8\% と，高校生の回答率が高かった. 胃潰瘍は誤りの選択肢であるが，この回答率は高校 生 $11.0 \%$, 高齢者 $2.7 \%$ と, 高校生の回答率が高 
Table 2. Rate of Correct and Incorrect Answers to Questions about Hypertension

\begin{tabular}{lccc}
\hline \hline $\begin{array}{c}\text { Knowledge about } \\
\text { hypertension }\end{array}$ & $\begin{array}{c}\text { High school } \\
\text { students } \\
(n=146)\end{array}$ & $\begin{array}{c}\text { Elderly } \\
\text { people } \\
(n=447)\end{array}$ & $p$-value \\
\hline Q1. Which is the definition of hypertension? & \\
Correct & $68(46.6)$ & $280(62.6)$ & $<0.001^{*}$ \\
Incorrect & $78(53.4)$ & $167(37.4)$ &
\end{tabular}

Q2. Which is the cause of hypertension? (multiple answers allowed)

$\begin{array}{lrr}\text { Correct } & 33(22.6) & 99(22.1) \\ \text { Incorrect } & 113(77.4) & 348(77.9)\end{array}$

Q3. Which is the disease associated with hypertension? (multiple answers allowed)

$\begin{array}{lrrr}\text { Correct } & 24(16.4) & 76(17.0) & 0.874 \\ \text { Incorrect } & 122(83.6) & 371(83.0) & \end{array}$

Q4. Which is the symptom of hypertension? (multiple answers allowed)

$\begin{array}{lrrr}\text { Correct } & 0\left(\begin{array}{l}0 \\ \text { Incorrect }\end{array}\right. & 1(0.2) & 1.000 \\ & 146(100) & 446(99.8) & \end{array}$

Q5. Which is the measurement position of blood pressure?

$\begin{array}{llrl}\text { Correct } & 99(67.8) & 388(86.8) & <0.001^{*} \\ \text { Incorrect } & 47(32.2) & 59(13.2)\end{array}$

Q6. Which is the recommended daily salt intake?

$\begin{array}{llll}\text { Correct } & 75(51.4) & 255(57.0) & 0.231 \\ \text { Incorrect } & 71(48.6) & 192(43.0) & \end{array}$

Q7. Which corresponds to the salt intake of $1 \mathrm{~g}$ of sodium?

$\begin{array}{llrl}\text { Correct } & 48(32.9) & 50(11.2) & <0.001^{*} \\ \text { Incorrect } & 98(67.1) & 397(88.8)\end{array}$

Q8. Which is the aerobic exercise? (multiple answers allowed)

$\begin{array}{llll}\text { Correct } & 76(52.1) & 254(56.8) & 0.314 \\ \text { Incorrect } & 70(47.9) & 193(43.2) & \end{array}$

Q9. Is the medicine for high blood pressure continued over a lifetime?

\begin{tabular}{lrrr} 
Correct & $40(27.4)$ & $204(45.6)$ & $<0.001^{*}$ \\
Incorrect & $106(72.6)$ & $243(54.4)$ & \\
\hline
\end{tabular}

Fischer's exact used for expected cell counts less than $5 .{ }^{*}$ Statistical sig nificance.

かった.

Q4 の回答内訳については, 肩こりのみ高校生 $26.0 \%$, 高齢者 $41.2 \%$ と, 高齢者の回答率が高い. それ以外の選択肢の回答率には差がみられなかった。

Table 4 では，高校生と高齢者において，普段の 食生活で塩分のとりすぎに注意していますかという 項目とアンケートの他の質問項目との関連を層別化 解析した結果を示した。ただし，高血圧と症状 （Q4）については，正答率が低いためこの解析の対 象から除いた。また，高齢者に関しては性別と年齢 についても解析項目に加えた.

まず，高校生の食塩摂取の意識は家族に高血圧の
Table 3. Contents of Answer to Questions about Hypertension

\begin{tabular}{lccc}
\hline \hline $\begin{array}{c}\text { Hypertension } \\
\text { knowledge measure }\end{array}$ & $\begin{array}{c}\text { High school } \\
\text { students } \\
(n=146)\end{array}$ & $\begin{array}{c}\text { Elderly } \\
\text { people } \\
(n=447)\end{array}$ & $p$-value \\
\hline $\begin{array}{l}\text { Q2. Which is the cause of hypertension? (multiple answers } \\
\text { allowed) }\end{array}$ & & & \\
$\begin{array}{l}\text { Excessive amount } \\
\text { of salt }\end{array}$ & $131(89.7)$ & $406(90.8)$ & 0.693 \\
$\begin{array}{l}\text { Obesity } \\
\text { Diabetes mellitus }\end{array}$ & $120(82.2)$ & $304(68.0)$ & $0.001^{*}$ \\
Lack of exercise & $71(48.6)$ & $158(35.3)$ & $0.033^{*}$ \\
\end{tabular}

Q3. Which is the disease associated with hypertension? (multiple answers allowed)

$\begin{array}{lrrr}\text { Heart disease } & 120(82.2) & 322(72.0) & 0.014^{*} \\ \text { Stroke } & 126(86.3) & 417(93.3) & 0.008^{*} \\ \text { Kidney disease } & 54(37.0) & 111(24.8) & 0.004^{*} \\ \text { Gastric ulcer } & 16(11.0) & 12(2.7) & <0.001^{*}\end{array}$

Q4. Which is the symptom of hypertension? (multiple answers allowed)

\begin{tabular}{lrll} 
Headache & $83(56.8)$ & $275(61.5)$ & 0.316 \\
Stiff shoulders & $38(26.0)$ & $184(41.2)$ & $0.001^{*}$ \\
Palpitation & $101(69.2)$ & $317(70.9)$ & 0.689 \\
Dizziness & $94(64.4)$ & $273(61.1)$ & 0.475 \\
\hline
\end{tabular}

* Statistical significance.

人がいることを知っていること（対象者の属性）と 関連している可能性が示唆された。高齢者について は，60-64 歳では塩分摂取に注意していないと回答 した割合が多かったのに対し，65-74 歳ではその割 合に差がなくなり，75歳以上では塩分摂取に注意 していると回答した割合が多くなっていた。さら に，高齢者では家族に高血圧の人がいることを知つ ていることと塩分摂取の意識は関連しておらず，知 識の項目である 1 日食塩の推奨摂取量を知っている こと（Q6）と関連していることが示唆された.

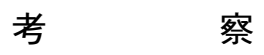

本研究から効果的な高血圧予防戦略を構築するた めの新たな知見が得られたと考えられる。調査した 集団における高齢者の血圧や食塩に対する意識は高 校生よりも高い結果となつた。唯一, 食塩含有量の 計算問題（Q7）の正答率は高校生のほうが高かつ たが, 大学紹介フェアに参加した学生のほうが, 高 齢者より化学の計算問題に普段から接していたこと が理由として推測される。回答内容の傾向では, 複 数選択肢の問題では高校生は高齢者よりも誤答を選 び易い可能性があった。

高齢者の正答率が高かった質問内容は高血圧の定 
義（Q1）や正しい血圧の測定部位（Q5)，高血圧 の治療（Q9）であった。これは高齢者のほうが周 囲に高血圧のひとが多く，また自身も高血圧である 人が多いためと考えられる。一方，高校生は高血圧 の病態に関する知識が少なく，薬をやめられると考 えている割合が多いことが明らかになつた．国民戦 略の観点からは若い世代から将来の自身に関係する 疾患であり，高血圧は世界的にも大きな問題となつ ていることを知ってもらう必要があると考える．高 校生と高齢者も正答率の低かった高血圧の原因 $(\mathrm{Q} 2)$ ，高血圧と関連のある疾患 $(\mathrm{Q} 3)$ ，高血圧と 症状（Q4）についてはこれから認識の強化に取り 組んでいかなければならない項目であると思われる.

Table 3 に示された回答の内訳を確認すると，Q2 については，高校生と高齢者ともに半数以上の人が 高血圧と糖尿病が結びついていない，Q3 について は，高血圧が脳梗塞や心疾患に関連することはわか るが，腎臟病と関連することを知らない人が多かつ た。そして，Q4 からは高血圧と症状を関連させて 考える人が多いことが明らかになった．高血圧は無 症状であり，日常において血圧を正確に測定するこ とが重要であることを教育していく必要があると思 われた。

本稿で報告した結果から，一般住民において健康 意識・知識に世代間の差があることが明らかになつ た.このように世代の高血圧に対する知識の差を埋 めていくことは将来の高血圧を予防していくために 重要であるが，その一方で，高血圧を意識すること 自体が QOL を障害するという報告がある。五した がつて，国民を高血圧予防のための健康行動ができ るように，マスメディア，企業，非営利団体，職 場・学校・家庭，保険者，専門家などの，健康関連 グループが協力し，それぞれの立場から国民の健康 行動を活性化していく必要がある.

われわれはさらに，塩分の取りすぎに注意してい る人とそれぞれの質問の回答内容との相関を解析し た (Table 4)。高校生では家族に高血圧のひとがい ることが減塩の意識を高める可能性が示唆された.

一方，高齢者では年齢がより高いほど減塩意識が高 い傾向があり，さらに，1日の食塩の推奨摂取量を 知っていることが減塩意識と相関している可能性が あった。今回の調査では, 減塩という行動化に至る には，高校生に関しては一緒に暮らす家族が高血圧
であるかという認識に左右され，高齢者では食塩に 関する知識が重要な項目であることが示唆された.

以上により，高校生と高齢者は食塩摂取の意識と 関連のある項目にも差が生じていることが明らかに なった.

これまでに，青少年における生活習慣に関する調 査は数多く報告されている，食生活，運動，等適切 な生活習慣を獲得するための健康教育を行い，健康 意識を高めていくことが大切である. $\left.{ }^{8}\right)$ 高校生の食 生活と自覚症状との関連について調査した報告で は，食塩の取りすぎは生活習慣病につながると思う 一方で，減塩を意識している高校生は少ない. ${ }^{9)} し$ かし，減塩を意識している高校生は減塩と関連深い 食行動がみられたと報告もあり，減塩意識を高める 健康教育の方法が重要であると思われる。本研究結 果から高校生への疾患や薬の教育には，自身の実体 験が行動につながり易い可能性があるため，健康に 関する体験型学習を提供できる機会が増えるとよい と考える.

高齢者の薬物治療においては，知識がそのまま健 康行動につながり易い可能性がある.したがって, プライマリケアを提供する地域の医療機関において 生活上で注意できる項目については知識を確認し, 情報を提供していく必要があると考える。しかしな がら, 外来診療において高血圧患者の塩分意識の改 善度は実際の塩分摂取と相関していない. ${ }^{10)}$ また, 高血圧クリニックと一般クリニックを対象にした調 査においては，どちらのクリニックにおいても塩分 摂取意識と実際の塩分㩒取は改善したものの，塩分 摂取の減少量は一般クリニックのほうが大きかっ た. ${ }^{11,12)}$ 食塩摂取に関する知識と意識と行動はかな らずしも一致していない可能性があり，減塩には減 塩意識以外の様々な要因が関与する可能性があるた め, 今後も更なる研究が必要と考える.

最後に，本研究にいくつかの制限があることを示 す。名古屋市の年金制度説明会の参加者と大学紹介 フェアに参加した東海地区の高校生を対象に行われ た調査研究である，日本には 60 歳を定年とする企 業や機関も多く，60 から 64 歳の年金制度説明会の 参加者も本研究の対象者に含まれている。また，今 回の調査では高校生に主眼をおいた調査であったた め, 本人の高血圧の有無ではなく, 家族の高血圧の 有無について確認されており，学歴，職歴，収入， 
Table 4. Relationship between Salt Intake and the Rate of Correct and Incorrect Answers to Questions about Hypertension

(a) High school students

\begin{tabular}{|c|c|c|c|}
\hline \multirow{2}{*}{$\begin{array}{l}\text { Rate of Answers } \\
\text { to Question }\end{array}$} & \multicolumn{2}{|c|}{ Salt intake consciousness } & \multirow[b]{2}{*}{$p$-value } \\
\hline & $\begin{array}{l}\text { Careful } \\
(n=72)\end{array}$ & $\begin{array}{l}\text { Not careful } \\
(n=74)\end{array}$ & \\
\hline \multicolumn{4}{|c|}{ Is there any history of high blood pressure in your family? } \\
\hline Yes & $27(37.5)$ & $16(21.6)$ & \multirow[t]{2}{*}{$0.046^{*}$} \\
\hline No or I don't know & $45(62.5)$ & $58(78.4)$ & \\
\hline \multicolumn{4}{|c|}{ Q1. Which is the definition of hypertension? } \\
\hline Correct & $36(50.0)$ & $32(43.2)$ & \multirow[t]{2}{*}{0.507} \\
\hline Incorrect & $36(50.0)$ & $42(56.8)$ & \\
\hline \multicolumn{4}{|c|}{ Q2. Which is the cause of hypertension? } \\
\hline Correct & $18(25.0)$ & $15(20.3)$ & \multirow[t]{2}{*}{0.555} \\
\hline Incorrect & $54(75.0)$ & $59(79.7)$ & \\
\hline \multicolumn{4}{|c|}{ Q3. Which is the disease associated with hypertension? } \\
\hline Correct & $14(19.4)$ & $10(13.5)$ & \multirow[t]{2}{*}{0.377} \\
\hline Incorrect & $58(80.6)$ & $64(86.5)$ & \\
\hline \multicolumn{4}{|c|}{ Q5. Which is the measurement position of blood pressure? } \\
\hline Correct & $45(62.5)$ & $54(73.0)$ & \multirow[t]{2}{*}{0.216} \\
\hline Incorrect & $27(37.5)$ & $20(27.0)$ & \\
\hline \multicolumn{4}{|c|}{ Q6. Which is the recommended salt intake? } \\
\hline Correct & $39(54.2)$ & $36(48.6)$ & \multirow[t]{2}{*}{0.513} \\
\hline Incorrect & $33(45.8)$ & $38(51.4)$ & \\
\hline \multicolumn{4}{|c|}{ Q7. Which is the salt intake of $1 \mathrm{~g}$ of sodium? } \\
\hline Correct & $26(36.1)$ & $22(29.7)$ & \multirow[t]{2}{*}{0.482} \\
\hline Incorrect & $46(63.9)$ & $52(70.3)$ & \\
\hline \multicolumn{4}{|c|}{ Q8. Which is aerobic exercise? } \\
\hline Correct & $36(50.0)$ & $40(54.1)$ & \multirow[t]{2}{*}{0.741} \\
\hline Incorrect & $36(50.0)$ & $34(45.9)$ & \\
\hline \multicolumn{4}{|c|}{$\begin{array}{l}\text { Q9. Is the medicine for high blood pressure continued over } \\
\text { a lifetime? }\end{array}$} \\
\hline Correct & $17(23.6)$ & $23(31.1)$ & 0.356 \\
\hline Incorrect & $55(76.4)$ & $51(68.9)$ & \\
\hline
\end{tabular}

* Statistical significance. (b) Elderly people

\begin{tabular}{|c|c|c|c|}
\hline \multirow{2}{*}{$\begin{array}{l}\text { Rate of Answers } \\
\text { to Question }\end{array}$} & \multicolumn{2}{|c|}{ Salt intake consciousness } & \multirow[b]{2}{*}{$p$-value } \\
\hline & $\begin{array}{c}\text { Careful } \\
(n=338)\end{array}$ & $\begin{array}{l}\text { Not careful } \\
(n=109)\end{array}$ & \\
\hline \multicolumn{4}{|c|}{ Is there any history of high blood pressure in your family? } \\
\hline Yes & $175(51.8)$ & $53(48.6)$ & 0.583 \\
\hline No or I don't know & $163(48.2)$ & $56(51.4)$ & \\
\hline \multicolumn{4}{|l|}{ Gender } \\
\hline Male & $268(79.3)$ & $95(87.2)$ & 0.069 \\
\hline Female & $70(20.7)$ & $14(12.8)$ & \\
\hline \multicolumn{4}{|l|}{ Age } \\
\hline $60-64$ & $97(28.6)$ & $46(42.2)$ & $0.010^{*}$ \\
\hline $65-69$ & $57(16.9)$ & $17(15.6)$ & 0.882 \\
\hline $70-74$ & $59(17.5)$ & $21(19.3)$ & 0.668 \\
\hline $75-$ & $125(37.0)$ & $25(22.9)$ & $0.007^{*}$ \\
\hline \multicolumn{4}{|c|}{ Q1. Which is definition of hypertension? } \\
\hline Correct & $215(63.6)$ & $65(59.6)$ & 0.495 \\
\hline Incorrect & $123(36.3)$ & $44(40.4)$ & \\
\hline \multicolumn{4}{|c|}{ Q2. Which is the cause of hypertension? } \\
\hline Correct & $80(23.7)$ & $19(17.4)$ & 0.187 \\
\hline Incorrect & $258(76.3)$ & $90(82.6)$ & \\
\hline
\end{tabular}

Q3. Which is the disease associated with hypertension?

$\begin{array}{lrrr}\text { Correct } & 64(18.9) & 12(11.0) & 0.058 \\ \text { Incorrect } & 274(81.1) & 97(88.9) & \end{array}$

Q5. Which is the measurement position of blood pressure?

$\begin{array}{lrrr}\text { Correct } & 298(88.2) & 90(82.6) & 0.144 \\ \text { Incorrect } & 40(11.8) & 19(17.4) & \end{array}$

Q6. Which is the recommended salt intake?

$\begin{array}{llll}\text { Correct } & 202(59.8) & 53(48.6) & 0.045^{*} \\ \text { Incorrect } & 136(40.2) & 56(51.4) & \end{array}$

Q7. Which is the salt intake of $1 \mathrm{~g}$ of sodium?

$\begin{array}{lrrr}\text { Correct } & 35(10.4) & 15(13.8) & 0.382 \\ \text { Incorrect } & 303(89.6) & 94(86.2) & \end{array}$

Q8. Which is aerobic exercise?

$\begin{array}{llll}\text { Correct } & 190(56.2) & 64(58.7) & 0.658 \\ \text { Incorrect } & 148(43.8) & 45(41.3) & \end{array}$

Q9. Is the medicine for high blood pressure continued over a lifetime?

\begin{tabular}{llll} 
Correct & $151(44.7)$ & $53(48.6)$ & 0.508 \\
Incorrect & $187(55.3)$ & $56(51.4)$ & \\
\hline
\end{tabular}

* Statistical significance.

mation and communication technology（ICT）の技 術が発達し，国民の健康情報の収集方法も世代毎に 多様化している可能性が高い。高血圧の改善のため には減塩・減量・運動・節酒など様々な健康行動が 重要であることも示されている. ${ }^{13)}$ 今後も食塩摂取 の意識のみに限定せず，世代間の健康意識や知識の 差に注目し，高血圧予防のための最適な健康行動に 結び付けていくための更なる研究が必要と考える. 
謝辞アンケートにご協力頂きました高齢者の 皆様, 高校生の皆様に深く感謝申し上げます。

利益相反＼cjkstart開示すべき利益相反はない.

\section{REFERENCES}

1) Ettehad D., Emdin C. A., Kiran A., Anderson S. G., Callender T., Emberson J., Chalmers J., Rodgers A., Rahimi K., Lancet, 387, 957967 (2016).

2) Udani S., Lazich I., Bakris G. L., Nat. Rev. Nephrol., 7, 11-21 (2011).

3) O'Donnell M. J., Xavier D., Liu L., Zhang H., Chin S. L., Rao-Melacini P., Rangarajan S., Islam S., Pais P., McQueen M. J., Mondo C., Damasceno A., Lopez-Jaramillo P., Hankey G. J., Dans A. L., Yusoff K., Truelsen T., Diener H. C., Sacco R. L., Ryglewicz D., Czlonkowska A., Weimar C., Wang X., Yusuf S., Lancet, 376, 112-123 (2010) .

4) The Japanese Society of Hypertension, "JSH Guidelines for the Management of Hypertension 2014," 2014.

5) Ministry of Health, Labour and Welfare, "Health Japan 21.": / http: / / www. kenkounippon21.gr.jp/kenkounippon21/about/ souron/index.html $\rangle$, cited 12 December, 2016.

6) The Japanese Society of Hypertension, “JSH Guidelines for the Management of Hyperten- sion 2009," 2009.

7) Mena-Martin F. J., Martin-Escudero J. C., Simal-Blanco F., Carretero-Ares J. L., ArzuaMouronte D., Herreros-Fernandez V., J. Hypertens, 21, 1283-1289 (2003).

8) Yano K., Okada S., Kan Y., Huzii K., Matsui E., Kawasaki Medical Welfare Journal, 14, 49-58 (2004).

9) Murai Y., Tamon R., Onishi S., Nishimoto K., Egami H., Nakamura K., Sato S., Journal of Japanese Society of Shokuiku, 9, 265-273 (2015).

10) Takahashi N., Tanabe K., Adachi T., Nakashima R., Sugamori T., Endo A., Ito T., Yoshitomi H., Ishibashi Y., Clin. Exp. Hypertens., 37, 388-392 (2015)

11) Ohta Y., Ohta K., Ishizuka A., Hayashi S., Kishida M., Iwashima Y., Yoshihara F., Nakamura S., Kawano Y., Clin. Exp. Hypertens., 37, 172-175 (2015).

12) Ohta Y., Ohta K., Ishizuka A., Hayashi S., Kishida M., Iwashima Y., Yoshihara F., Nakamura S., Kawano Y., Clin. Exp. Hypertens., 37, 454-458 (2015).

13) Appel L. J., Champagne C. M., Harsha D. W., Cooper L. S., Obarzanek E., Elmer P. J., Stevens V. J., Vollmer W. M., Lin P. H., Svetkey L. P., Stedman S. W., Young D. R., JAMA, 289, 2083-2093 (2003) . 